The Geneva Papers on Risk and Insurance, 23 (No. 87, April 1998), 224-246

\title{
Information Disclosure in a Competitive Insurance Market - The Government Role
}

\author{
by Kruno Kukoc*
}

\begin{abstract}
The paper examines the role of information disclosure in a competitive insurance market and the role of government in facilitating the flow of information between insurance market participants. After an introduction to the theoretical framework, the paper outlines some specifics of information disclosure in insurance and the role for the government. It distinguishes between three main pillars of information disclosure in insurance: disclosure of financial information, disclosure of information related to product, price and redress mechanisms and disclosure of factors relevant to the risk. The major part of the paper is devoted to insurance regulation and contemporary regulatory issues dealing with disclosure of information in Australia. Finally, the paper emphasises the importance of information disclosure as a regulatory instrument, recognises its limitations, and outlines some remaining public policy issues.
\end{abstract}

\section{Introduction}

Information asymmetry is one of the most common forms of market failure in insurance.

Because of the risks attaching to direct intervention by government, disclosure of information is becoming more widely used as an instrument of financial regulation.

This paper examines the role of information disclosure in insurance and the role of government in facilitating the flow of information between insurance market participants.

* Insurance and Superannuation Commission, Australia, February 1997. The author has received helpful comments from Richard Smith, Dr Daryl Roberts and Robert McCombie. I gratefully acknowledge the support and contribution of Don Gruber. 
It outlines some specifics of information disclosure in insurance and deals with issues such as disclosure of financial information (rating versus supervision) and disclosure of factors relevant to the risk.

The paper also provides an outline of the insurance regulation in Australia dealing with information disclosure and some contemporary regulatory issues in this respect.

In conclusion, the paper emphasises the importance of information disclosure as a viable and efficient regulatory tool, but also draws attention to some caveats and limitations of information disclosure in insurance.

\section{Market failure in insurance}

The three most common forms of market failure in insurance are:

- information asymmetry;

- adverse selection; and

- systemic risk

\subsection{Information asymmetry}

"Information asymmetry" refers to the situation where one party, usually the seller, has information that is not available or understandable to the other party, the buyer.

In their ignorance, buyers may make decisions that are not in their best interest. Not only can this have negative individual consequences but it may also have negative market and social implications. The feedback provided to sellers may encourage and stimulate poor market practice rather than provide competition on the basis of efficient and quality service. As a consequence, the clearance (equilibrium) quantity of insurance products in the market may be higher than the social optimum creating a deadweight loss for society. The following diagram shows the effect.

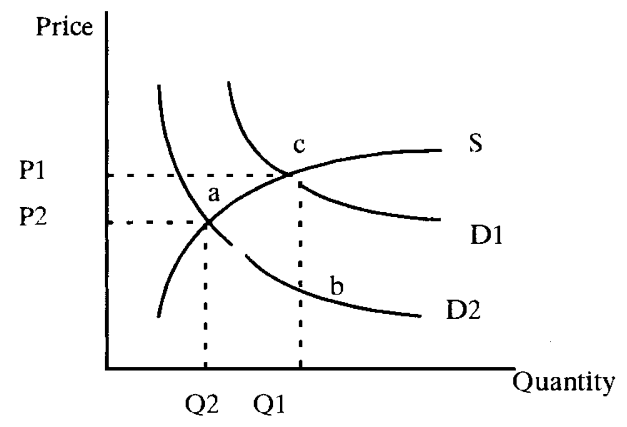

DI,QI,P1 - Demand, clearance quantity and price when policyholders do not have full information.

D2,Q2,P2 - Demand, clearance quantity and price when policyholders have full information.

abc - Deadweight loss.

One of the most common ways to remedy the problem is by information disclosure which is an important instrument of modern financial regulatory policy. The following tables show the difference between situations with and without information disclosure. 
Table 1: With Information Disclosure

Disclosure of full information $\longrightarrow$ Buyers receive information and make decisions<smiles>C[13CH]</smiles>

Utility expectations (arising from individual risk management strategies) influence the particular structure and quantity of insurance products demanded<smiles>C[14CH3]</smiles>

Sellers receive feedback from market participants and adapt supply (products, prices, quantity)

Table 2: Without Information Disclosure

Selective information $\longrightarrow$ Buyers make decisions based on selective information<smiles>C[13CH]</smiles>

Utility expectations influence the structure and quantity demanded

Sellers receive feedback from $\downarrow$ market participants and adapt
supply (products, prices, quantity) $\downarrow$ Individual experience - costs and benefits<smiles>C1CC1</smiles>

Buyers review and possibly revise decisions - time and costs involved

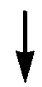

Changes in the structure and quantity of demand and supply

It is likely that, in the situation of selective disclosure, the market mechanism will still work but with a longer time for adjustment and with unnecessary loss resulting from time and cost consuming, experience based, adjustments. 
In insurance particularly, the loss involved is significantly higher and may be socially unacceptable. Families may lose their homes, dependants may be left without breadwinner's financial support, innocent third parties may be left without indemnity for loss suffered and business may be closed because of an accident.

From a consumer's point of view an insurance product is a mixture between an experience and a post-experience good. Being an intangible and technical product, consumers cannot easily determine the quality of the good before they spend the money. The true quality of the good is revealed only after they consume the good, including through the claims process. If there is no claim, deficiencies may not become apparent. The possible consequences for consumers include price and search costs as well as loss of welfare arising from uninsured events.

"Information asymmetry" in insurance also refers to the situation where sellers, the insurers, do not have full information about the risk to be assumed. In their ignorance, they make decisions that are costly and not in their best interest. These costs are later spread throughout the economy in the form of higher insurance premiums. The incidence of such behaviour may be quite significant in highly competitive markets where companies are driven to absorbing bad risks by competitive pressures.

\subsection{Adverse selection}

The lack of information can create situations where insurers cannot distinguish among different risk classes of policyholders. This type of situations may have a significant effect on competitive insurance markets and may ultimately lead to a non-existence of the equilibrium (static equilibrium) ${ }^{1}$. Within each risk category, some people will have a higher than average risk of loss and some a lower than average risk. Those with higher than average risk will tend to find insurance attractive and buy it, and those with lower than average risk will not. The more people from the first group and the less from the latter who buy insurance, the higher the average risk. As a result, the price of insurance goes beyond an actuarially fair level. To quote Rothchild and Stiglitz:

"The high risk individuals exerted a dissipative externality on the low-risk individuals"2

A good example of this in Australia is our private health insurance system, which adopts a community rating principle. The young are not taking out cover because of the high costs of subsidising the old, with the result that the overall cost of health cover is increasing.

Modern information technology and insurance practice has somewhat reduced the problem of adverse selection. Still in some areas (liability, health insurance) the problem might arise and governments may decide to intervene making some forms of insurance mandatory.

Therefore, an improved flow of information from policyholders to insurers is an important precondition for actuarially fair pricing of insurance products and an efficient insurance market.

\footnotetext{
1 Rothschild/Stiglitz.

${ }^{2}$ Rothschild/Stiglitz.
} 


\subsection{Systemic risk and public confidence}

In a modern market economy, financial institutions make their own investment decisions without government interference. The need for stability in the financial system is based on the notion that the failure of a financial institution may, through contagion effects, undermine stability and public confidence in the financial sector as a whole.

This is the reason why governments set minimum standards of financial soundness for companies selling financial products or services. These standards are intended to minimise the risk of loss for consumers and the general public should a company's financial position become weak, and to preserve a reasonable level of public confidence in the industry as a whole.

When a failure does occur, it is important that the institution leaves the industry in an orderly manner, and that the interests of investors and policyholders are protected. Government regulation is an important instrument of achieving these objectives.

Regulation also helps to ensure that the risk of loss is borne by shareholders and not by clients and taxpayers. It forces management structure to be more accountable and to take better care when making investment decisions.

It may be argued that systemic risk can arise only from the banking system because of its payments function while the risk is almost negligible in insurance. However, this is only partly true since it is often forgotten that insurance is an important risk management tool which helps people and business to plan their lives and investments in the long term. The costs of increased uncertainty across the economy arising from a lack of confidence in the insurance sector may be quite significant. The Parreto efficient outcome in a two-period (present and future) economy may not be achieved without a stable and secure insurance sector.

\section{Risks of insurance regulation}

As with regulation in other financial sectors, there are number of issues of potential concern for government in insurance regulation. These include:

- Moral hazard

- Rent seeking behaviour

- Heavy handedness

- Regulatory gaps and overlaps - consistency versus specificity

- Self-regulation is more effective

\subsection{Moral hazard}

Moral hazard in insurance regulation refers to the incentive insurance companies have to take excessive risk without appropriate safeguards and risk management strategies in place, in the situation where their potential losses are covered by some kind of guarantee from the government.

The overall result of regulation can thus become negative since taxpayers may end up paying more than policyholders would lose if there was no government intervention. 
On the other hand, policyholders and the general public, the main beneficiaries of government financial regulation, can also suffer losses because of too much reliance on government regulation. Despite their best efforts, governments cannot realistically eliminate the risk of loss arising from financial failure or from a determined act of theft or fraud. However, the mere existence of government regulation and supervision can make policyholders less careful and reduce the effect of the "caveat emptor" principle in the market.

Therefore it is important that government regulation only helps to reduce the risk of financial losses and that it does not remove the risk completely. The emphasis of government regulatory efforts should be devoted to empowering consumers to protect themselves in the market ${ }^{3}$.

\subsection{Rent seeking behaviour}

There is a possibility that regulators could, over time, become captured by the interests of the industry they regulate. Bias in the use of discretionary powers can lead to economic inefficiency and increased social costs of regulation.

Rent seekers usually emerge from government intervention. Any government intervention creates winners and losers. Those who receive benefits either in the form of lessened competition or increased security and protection become rent-seekers or lobbyists for continuing government intervention.

After some period of time it becomes harder and harder to reduce government intervention even though the intervention has failed (eg. by producing more social costs than benefits).

\subsection{Heavy handedness}

When regulating the financial sector, governments must always strike a balance between the need for security and a need for efficiency. In order to increase security government may introduce heavy-handed measures which may not only impose compliance costs but may also result in various inefficiencies arising out of the government interference (allocative and dynamic inefficiencies).

The aim of regulation should be to strengthen a company's own capacity to deal effectively with adverse market developments.

\subsection{Regulatory gaps and overlaps - consistency versus specificity}

Financial regulation may not be uniform across the sector as different rules are applied to different institutions and different products. Regulatory requirements (and costs) are usually tailored to the needs and characteristics of specific industries within the sector (banking, insurance, superannuation). Uniformity can sometimes impose unnecessary costs on some industries without being fully effective (eg, prudential standards imposed on investment and deposit taking institutions may be inappropriate

${ }^{3}$ see disclosure of information. 
when applied to risk taking financial institutions). The costs involved will be ultimately passed to the rest of society through higher prices of financial products.

However, the application of different rules for different parts of the financial sector has the potential to impose apparently unequal regulatory costs on institutions who compete against each other with functionally similar financial products. This may impair the "competitive neutrality" which is an important precondition for efficient market operation. An example of this in Australia is seen in our life insurance and unit trust industries. Both offer investment linked products, the life product is heavily supervised, the trust product is not.

There is also a trend towards the formation of financial conglomerates, financial groups consisting of financial entities offering different products and operating under different regulatory standards (banks, securities companies, life offices, insurance companies). The emergence of these poses significant questions for financial regulators such as: whether there is a risk that the capital position of healthy segments of a conglomerate might be weakened because the parent company feels obliged to support an ailing segment; and whether public confidence in the entire conglomerate might be weakened because of emerging problems in one segment.

\subsection{Self-regulation is more effective?}

Self-regulation by industry associations, such as codes of conduct, is an effective and flexible way of achieving acceptable industry standards. In the appropriate context and within an adequate regulatory framework, they can provide a viable alternative to government regulation, with its attendant costs and rigidity. Given industry support and commitment it can sometimes achieve a better outcome than government regulation. Selfregulation usually imposes best practice standards while regulation protects minimum standards in the industry. In addition, compliance may be at a higher level than is the case with regulation, bearing in mind industry ownership of the self-regulatory mechanism.

Market supervision and control through ratings systems have also been successfully used as an instrument for enhancing accountability and transparency in the financial sector. Financial regulators increasingly use rating agencies and their assessments to make their own function more effective. For example, British regulators use ratings to help determine the quantum of reserves which securities firms should set aside against their bond holdings, Japan's Finance Ministry allows only high rated borrowers to sell bonds to Japanese investors and New Zealand relies on disclosure of ratings instead of a formal prudential arrangements.

\section{Public policy and information disclosure in insurance - Where the government sits?}

Because of these actual and potential risks of government direct intervention, information disclosure has become a more widely used regulatory instrument. Governments have become increasingly reluctant to use other, more intrusive, forms of regulation.

In insurance in particular, information flow among market participants is of indispensable value for the efficient operation of the market. Information disclosure can 
achieve policy outcomes without creating unwanted side effects or inefficiencies in the economy.

Disclosure of information in insurance as is the case in other sectors of the economy, can enhance competition, help consumers to "shop around" but most importantly it can help consumers to develop a better and more certain risk management plan for their future.

Nevertheless, information disclosure in insurance is more difficult and complex than in other industries. The complexity of insurance products and the risks to which insurance business is exposed have contributed to these difficulties.

Information disclosure in insurance needs to deal with issues such as the level of knowledge of consumers, market power of product providers and distributors and competition in all segments of the market (production and distribution). For example, in the Australian consumer credit insurance market the level of competition among insurers is reasonably high but the product marketing channels involving the packaging of insurance with credit products has meant that the persons who benefited from the competition were intermediaries (mostly lending institutions through higher commissions). Policyholders have ended up paying a higher price for cover while insurers are struggling with high expense ratios. Therefore, the Government intervened and prescribed rules for information disclosure in order to promote competition in the distribution segment of the CCI market.

There are three main areas of information disclosure in insurance:

- disclosure of financial information;

- disclosure of information related to product, price and redress mechanisms; and

- disclosure related to the declaration of factors relevant to the risk.

\subsection{Disclosure of financial information}

Disclosure of financial information is a critical precondition for a better and more effective insurance market. It stimulates better performance and enhances the transparency and accountability of market participants. Disclosure of financial information can help policyholders reduce the risk of losses arising out of the financial failure of the insurer.

Normally, companies will not disclose financial information unless they think it can enhance their public image. Therefore, to level the playing field and increase consistency in information disclosure, the government must intervene.

Government can achieve greater disclosure of information either through:

- regulating mandatory self-disclosure by companies; or

- publishing information obtained in the course of its regular supervisory duties

The type and complexity of the information which is to be disclosed will depend on the purpose of its use. In modern market economies with a strong presence of rating agencies, financial advisory and broking industries the information required fron these so 
called "market evaluators" will be more comprehensive. However, the needs of an ordinary consumer in an environment of government financial supervision, rating agencies and independent advisers, would be for more simplistic information.

This raises an issue of balance between the needs of ordinary consumers and professional evaluators. This issue is closely related to a modern dilemma of ratings versus government supervision, ie., do we need government supervision and government's disclosure of information to assist ordinary policyholders in a market where sophisticated rating and financial advisory industries services are readily available?

In other words what information should be disclosed, by whom and for what purposes?

The important distinguishing points between government supervision and rating agencies assessments are:

- different objectives

- availability of information

- evaluation approach

\subsection{Different objectives}

Rating agencies are private agencies and their objectives are normally different from those of a public regulator. For example an important objective for a rating agency may be to increase market share which may lead to the type of conflict of interest already experienced in US where a rating agency allegedly breached the antitrust rules by issuing a so called "hostile ratings."

Rating agencies are generally highly competent and professional organisations. However, they earn their money by charging fees to those who issue policies and not to those who buy them. This can create a perverse incentive for rating agencies to give a lower unsolicited rating to non-clients to encourage them to become clients in future. This incentive is even stronger under currently prevailing oligopolistic circumstances where a couple of big rating agencies dominate the world biggest markets. Therefore, the issue may be who is going to regulate and rate the rating agencies?

\subsection{Availability of information}

Rating agencies can sometimes have to deal with less information than is available to government regulators. This is particularly the case with involuntary ratings where the only available information is from publicly available accounts. Even if a full statutory disclosure of financial information is achieved, the availability of relevant information would still be lower than the situation where the regulator has developed a net of formal and informal channels of communication with the companies over years. Indeed, companies may not have the same incentive to fully disclose all relevant information for public ratings purposes as they have in the situation of government supervision which is intended to reduce the risk of their failure.

In insurance, in particular, bearing in mind the multiple risks involved (actuarial plus market and credit risks) and the various risk management tools available (legal risk 
management, reinsurance and derivatives contracts) information related to financial accounts cannot provide the full picture of a company's financial position.

\subsection{Evaluation approach}

Rating agencies have a different approach to the evaluation of financial performance than government regulators. Rating agencies promote best practice, which is in accordance with the important market role they have:

to stimulate better performance in the market and enhance transparency and accountability of market participants.

In this game there are always winners and losers.

On the other hand, regulators defend a statutory minimum, line in the sand. This enables all market participants to participate in the game if they satisfy minimum standards so that no one is hurt, or the risk of loss is minimal. No one is a loser and the winner is the policyholder who has a variety of choice, regardless of whether the company is big or small, with temporarily better or poorer financial performance. The policyholder, therefore, can choose according to other important factors such as price, product differentiation, quality, with minimal risk that the choice may be fatal for his or her financial well-being. This not only benefits consumers but also enhances competition, enabling smaller companies to earn their place in the market. This may particularly become important in so called market "niches" with highly technical and specific risks covered.

So, there is an important difference between regulators and rating agencies. The difference arises from their different roles in the economy and their different objectives. However, the complementary roles may provide for a better and more efficient financial supervision in the future. Rating agencies stimulate best practice while government agencies make sure "the deep pocket syndrome" does not prevail in the market which may ultimately lead to a monopolistic situation.

Therefore, in order to achieve this balance, Government has, apart from its supervisory function (defender of minimum standards), an important role to establish rules of information disclosure that will not only satisfy ordinary policyholders but will also offer valuable information to more sophisticated market evaluators. In addition, any government action should not undermine the "level playing field" in the market.

\subsection{Disclosure of information related to product, price and redress mechanism}

In insurance, product disclosure is about the contract, coverage and exclusions. A policyholder or adviser needs to know exactly what risks are covered and what risks are excluded from the coverage. These are important elements of an individual's risk management decisions. Lack of information in this area may cause serious troubles to policyholders but also impose huge costs to society in some instances (liability claims).

Policyholders need also to know about the premium and any additional charges such as agents commissions in order to make better comparisons and effectively "shop around" in the market. 
Readily available information about internal and external redress mechanisms can help reduce litigation costs and increase overall public confidence in the sector.

\subsection{Disclosure of factors relevant to the risk}

An established principle in insurance for many centuries has been that the viability of insurance underwriting depends on the insurer having correct information about the risks assumed.

The traditional view in common law countries was that an insured is better informed about the characteristics of the risk and that the onus should be on the insured to disclose everything that a prudent insurer would consider relevant to the decision to accept the risk and set the premium. The information required by a "prudent insurer" was the benchmark of disclosure. Over time, insurance law and practice have become less severe with the introduction of a reasonable person in the circumstances test (Australia - Insurance Contracts Act, UK - Statement of insurance practice, US and Canadian case law). The test focuses on the person making a disclosure and compares the behaviour of that person with the likely behaviour of the reasonable person in the same circumstances.

\subsection{The test deals with three issues:}

- Would a reasonable person in the circumstances have knowledge of the relevant factors?

- Would a reasonable person in the circumstances have knowledge that the factors were relevant for the insurer's decision?

- Does the term "circumstances" include only objective, extrinsic circumstances or include individual idiosyncrasies such as education, literacy and mental condition?

Given the complexity of insurance contracts these issues have become contentious. While the legal profession and consumer advocates have been inclined to interpret the "reasonable person test" as one of the knowledge of a normal person with full consideration of individual circumstances, insurance companies are inclined to the view that only extrinsic factors such as the environment in which the contract was signed are relevant.

Both the UK (in 1979) and Australian (1980-81) Law Reform Commissions recommended a reasonable person test which would take into account the insured's individual circumstances. In both countries the industry was successful in lobbying the governments to reject the proposal.

However, it may be that this issue is becoming less relevant. The long established principle of "utmost good faith" in insurance obliges an insurer to provide guidance as to what factors it considers relevant to the decision to accept the risk and set the premium. In many countries contemporary law gives special importance to the items in the questionnaire or the proposal form. For example, the law denies legal remedy to the insurer for non-disclosure in the absence of the clear and relevant questions in the proposal form. 


\section{Information disclosure in insurance regulation of Australia}

\subsection{Prudential supervision}

The prudential supervision covering the general (non-life) insurance industry in Australia derives from the Insurance Act 1973 and Insurance Acquisitions and Takeovers Act 199.

One objective of the legislation is to set minimum prudential standards without creating unnecessary barriers to entry or exit from the market. The legislation does not control premium rates, contract wordings or the flow of general insurance business into or out of Australia. From a prudential point of view the legislation, which is administered by the Insurance and Superannuation Commission (ISC) - a Federal Government Agency, is working well and Australia has not had a significant failure for a number of years.

The ISC supervisory system is based on the review of quarterly and annual audited returns, with supporting powers of inspection. The system, which is based on historical information, is not designed to prevent all failures but rather seeks to minimise the risk of failures and provide for orderly entry to and exit from the market. The supervisory system provides for the disclosure of key financial information.

\subsection{Disclosure of solvency}

The ISC decided to proceed further down the path of solvency disclosure following international and domestic moves towards the disclosure of the capital adequacy requirements of banks and the solvency of life insurers. Further, brokers and other analysts of general insurers have urged the ISC to move towards disclosure of the solvency information.

The ISC examined the available options against the background that each insurer's underwriting account, profit and loss account, balance sheet and audit certificate had been publicly available for some time.

The advantage of the move to disclose the actual solvency calculation for insurers is that a key financial indicator would be available to persons seeking to assess the financial strength and viability of authorised insurers in Australia. The task was, nonetheless, how to achieve disclosure of simple but meaningful information, which would satisfy policyholders and independent evaluators.

Perhaps the ideal would have been disclosure of some form of risk based solvency measure which would take into account differences in portfolio risks between insurers. However, this would involve a major (and contentious) development exercise. Our actual options included:

- disclosure of the minimum solvency required by legislation (net assets less statutory exclusions such as loans to directors) leaving it to the analysts to compare this with available balance sheet information as a measure of overall strength; 
- disclosure of actual solvency with or without related body assets ${ }^{4}$.

Other issues arose on the liabilities side. For example, what basis of determining long-term liabilities is acceptable and sufficiently consistent to allow meaningful comparisons. Should there be some attempt at reasonable standardisation before proceeding to disclosure? While we have a comprehensive general insurance accounting standards in Australia, we are yet to reach the position of standards which could be applied for the evaluation of long term liabilities. The resulting problem is that companies adopting more conservative prudential margins in their outstanding claims provisions would have lower solvencies disclosed.

A further issue was whether it would be more appropriate to disclose the level of "solvency" or "capital adequacy" required to meet the ISC's reinsurance or risk retention requirements. Apart from minimum solvency test of $\$ 2$ million, $20 \%$ of net premium income in Australia, or $15 \%$ of net outstanding claims in Australia, whichever is the greatest, the ISC may require an additional buffer above the minimum solvency requirements where the level of retention per risk or event is high.

In June 1996, the ISC proposed that each general insurer disclose in its publicly available annual audited returns to the ISC both its minimum and actual solvency margin, net of assets excluded by statute and unapproved related body assets. It was also proposed that each insurer be required to confirm that its current reinsurance arrangements had been approved by the ISC

Industry responses raised concerns that the information may be misunderstood by users particularly because of differing assumptions involving the estimate of outstanding claims provisions. It was also suggested that the proposals be deferred pending proposed legislative changes in respect of related body assets ${ }^{5}$ and the results of the Wallis Inquiry into the Financial System ${ }^{6}$.

As a result, the ISC has decided to limit the disclosure of solvency information for the time being to disclosure of each company's minimum solvency requirement under the Insurance Act.

Minimum Insurance Act solvency is a requirement over and above commercial solvency, but is not an adequate measure of its own of overall claims paying ability or financial strength. Other significant factors that would normally be taken into account to assess claims paying ability and capacity to take on risk exposure include access to additional capital, reinsurance, managerial and systems strength. Also, some insurers may choose, for various reasons, not to seek ISC approval, for solvency purposes, of all eligible

${ }^{4}$ Under Insurance Act a "related company" is one where there is more than $25 \%$ interest (either through share ownership or control of votes). While investments in related companies are normally excluded by the Act in determining solvency, the Commissioner has a discretion to override that exclusion in certain circumstances.

${ }^{5}$ The amendment to Insurance Act will extend the reporting, direction and investigation powers of the Act to related bodies corporate where considered necessary by the Commissioner, and with the agreement of the related body. On the other hand it will streamline the approval of the assets invested in related companies for solvency purposes.

${ }^{6}$ see later in the text. 
related body assets. The ISC expects the analysts to take into account these factors as well. Solvency disclosure is not a substitute for more broadly based security assessment of individual insurers.

For these reasons the disclosed solvency information will contain a warning that other information such as reinsurance, approved related body assets, managerial and systems strength, should also be considered in order to assess the overall financial strength of the company.

The industry has also set up a Working Party in order to develop a standardised approach to evaluation of outstanding claims provisions (OCP). It is expected that this will enable the disclosure of some better measure of insurer's financial strength in the future.

\subsection{Market supervision}

Apart from its prudential role under the Insurance Act the ISC also administers the Insurance Contracts Act 1984 and the Insurance (Agents and Brokers) Act 1984. The major objective is to promote fair and open dealings in the insurance market.

\subsection{Insurance Contracts Act}

Based on recommendations made by the Australian Law Reform Commission (ALRC) in the early eighties, the Insurance Contracts Act was introduced to improve the amount of information flowing between insurers and insureds and to ensure that insurance contracts operated more fairly.

Prior to the introduction of the Act, insurance contracts were arranged, and disputes settled, according to common law principles some of which dated back to the 16 th century. They evolved from complex business arrangements, particularly marine insurance under which the balance between insurer and insured was very much in favour of the insurer. These principles presumed that "the insurer takes a bet and the insured knows all the details'. There was also the "prudent insurer test" which held that a fact must be disclosed by a policyholder if it would affect the mind of a prudent insurer either in accepting a risk or in fixing a premium.

While these principles may have been appropriate in establishing the rules of the game for fairly technical and complex risks such as marine insurance, it was not clear that that they were appropriate for insurance contracts generally, and the consumer classes of insurance in particular.

The Insurance Contracts Act brought the Australian law of insurance contracts into the 20 th century.

To increase the flow of information between insurers and insureds the Act uses three main devices:

- the duty of utmost good faith;

- the duty of disclosure; and

- the standard cover provisions 


\subsection{The duty of utmost good faith}

The duty requires the parties to insurance contracts to show the highest degree of honesty and integrity towards the other party, to be full and frank in disclosure and to act with fairness.

\subsection{The duty of disclosure}

The duty of disclosure imposes an obligation on intending insureds to disclose all relevant information to the insurer before a contract of life or general insurance is entered into. The matters that have to be disclosed are those that insured knows and that a reasonable person would knew to be relevant to an insurer's decision to accept the proposal and to set the premium.

The insurer has a duty to inform the insured about the duty of disclosure and, under current ISC's proposals for amendments to the $\mathrm{Act}^{7}$, to ask relevant questions.

\subsection{Standard cover}

Standard cover provisions of the Contracts Act are aimed at ensuring that unexpected exclusions or limitations in the domestic classes of insurance (motor vehicle, home content and building, sickness and accident, consumer credit insurance, etc.) come to the attention of the insured before a policy is made.

The provisions in the Act clearly list the events covered and exclusions in the domestic classes of business which reflect the level of cover normally available in the market, or which insured might expect. Insurers may market products which differ from standard cover contracts providing that they clearly inform the insured in writing of the differences.

In addition to improving flow of information between parties to insurance contracts the Act also sets fair play rules in respect of cancellation of policies, fraudulent claims, averaging provisions and third party claims.

\subsection{The ISC's administration of the Act}

The Act was originally drafted on the basis that it would be self-enforcing, ie, enforcement and compliance would be a matter for the parties to the contract and the courts.

As a result of problems occurring in the consumer credit insurance and life insurance resources to enforce contracts through the courts, the Act was amended in 1994 to enable its active enforcement and administration by the ISC.

The ISC's main objectives in its administration are:

- to ensure that the Act achieves full information flow and strikes a fair balance between the interests of insurers, insureds and the broader community;

\footnotetext{
${ }^{7}$ see Review of the Act.
} 
To achieve these objectives, the ISC has promoted the development of free and easily accessible facilities to handle insurance enquires and complaints, and the development of a self-regulatory Code of Practice by the general insurance industry

In addition the ISC also:

- monitors legal decisions, insurance complaints and the effectiveness of the industry dispute resolution facilities and Code of Practice;

- reviews insurance documentation and administrative arrangements of insurers;

- promotes education and public awareness about the Act.

The ISC may also take representative action on behalf of insureds when it is in public interest to do so.

\subsection{Review of the Act}

During 1996, the ISC brought to a conclusion a broad review of the Act after ten years of operation.

In the ISC's opinion the Act has stood up well to the changes in the market and technology, thus performing its communication role efficiently and for the benefit of both insureds and insurers.

Nevertheless, the ISC proposed some important amendments related to the duty of disclosure.

\subsection{Duty of disclosure}

At present the Act imposes on the insured a very onerous, broad duty to disclose all matters that the insured knows, or should reasonably know, is relevant to the insurer's decision to accept the risk and to establish a premium. On the other hand there is no legal obligation for insurers to outline the factors they consider relevant for the decision to accept the risk and fix the premium.

The Claims Review Panels (an independent industry dispute resolution body) has suggested that the statutory duty of disclosure should require only that the insured give truthful answers to specific questions relevant to the risk for which cover is sought. This is consistent with the requirements of the Code of Practice.

After careful examination of the issue and consultation with interested parties, the ISC concluded that in accordance with the "utmost good faith" principle and existing practice in domestic classes of insurance, insurers should be legally required to ask specific and relevant questions about the risk.

However, the ISC also decided to preserve a broad duty of disclosure which would still require policyholders to disclose information not asked in the questionnaire but which a reasonable policyholder in the circumstances would know to be relevant for insurers decision about the risk. The requirement for insurers to ask specific questions would enable courts to reach a more balanced decision in the situation where the insurer did not ask the relevant question and the policyholder was unable to comply with the broad duty of disclosure. 
The main reason for this decision was that the duty of disclosure is a crucial requirement of insurance law and insurance business practice. The nature of insurance business is such that there still may be a need for a broader duty of disclosure in the legislation. With recent rapid market and technological developments and the emergence of more sophisticated and comprehensive risks, we may have a situation where questions cannot anticipate all of the relevant information which an insured might know about his own particular situation and possible risks involved. This of course, should not relieve the insurer from its "utmost good faith" obligation to outline factors it considers relevant to the risk.

\subsection{Direct marketing}

One of the interesting issues which the Commission considered in its review of the Act was direct marketing and, more specifically, tele-sales of insurance products. More specifically, the issue involved consideration of the information disclosure required by the Act in the circumstances of paperless transactions.

While the problem does not seem to be great in the case of electronic commerce which appears to accommodate the Act's requirement for written disclosure ${ }^{8}$, telephone sales proved to be more difficult. After some misunderstandings and conflicting legal opinions, the ISC and the industry agreed that the Act has the flexibility to accommodate pre-contractual oral disclosure if it is followed by written disclosure.

This has enabled the industry to accommodate telemarketing while at the same time ensuring the consumer is fully informed. ${ }^{9}$

\subsection{Disclosure in co-insurance and group policies}

One of the most difficult issues related to disclosure of information under the Act is disclosure in the circumstances of co-insurance and group policies.

In the case of co-insurance, the issue is how to deal with situation where the rights of innocent co-insureds are affected by the negligence or fraud of their co-insured. At present the Act considers disclosure made by one co-insured as joint disclosure of all co-insureds.

In group policies, the issue is one of the rights and obligation of beneficiaries under the policy in respect of disclosure when a central organiser (eg, employer) takes out the policy for the benefit of all of the members of a defined group (eg, employees). When the central organiser is the contracting party, it has the disclosure rights and obligation despite the fact that the beneficiaries have the information about the risk. The various statutory notices are required by the Act to go to the insured and not to the beneficiaries.

Both situations highlight the difficulties and complexities of information disclosure in insurance.

\footnotetext{
${ }^{8}$ Australian law accepts disclosure by electronic means as disclosure "in writing".

${ }^{9}$ Telemarketing has become one the most common selling techniques in some domestic classes of insurance in Australia (eg, around $80 \%$ in the motor vehicles class).
} 


\subsection{Agents and Brokers Act}

The main purpose of this Act is to improve the stability of the distribution system and to protect the insured from inappropriate and unprofessional conduct of intermediaries, particularly in the area of information and money flow from and to a policyholder.

Complex financial products such as insurance are often purchased on the basis of advice sought by the consumer. In many cases the consumer seeks objective advice based explicitly on an understanding of his or her individual circumstances. If an agent or adviser is called upon for advice, the consumer requires the agent to serve the consumer's interest.

In order to appropriately regulate intermediaries, the basic presumption of the Agents and Brokers Act is that brokers are independent intermediaries acting on behalf of insureds and agents are intermediaries acting on behalf of insurers. Consequently, the Act requires registration of insurance brokers who must have an insurance broking trust account and professional indemnity insurance. On the other hand, the Act makes insurers responsible for the actions of agents. The Act also deems premiums held both by agents and brokers to be paid to the insurer.

From a conceptual point of view, a broker should not act on an insurer's behalf and receive commissions from insurer. However, they have been receiving such commissions for a very long time. The Australian Law Reform Commission, and subsequently the ISC, recommended mandatory disclosure of commission as an intermediate regulatory solution. However, the industry successfully lobbied the Government with the result that disclosure is on request of the insured only. Needless to say, it is not often requested.

Under the Act, brokers are required to clearly disclose information such as name and place of business of the insurer, if it is acting under agency agreement or binder and any non arms-length relationship with an insurer.

\subsection{Life Act (new consumer part)}

In accordance with main principles and standards of the Insurance Contracts Act, the new, consumer provisions of the Life Act, will introduce more detailed, market behaviour and consumer protection standards related to life insurance products.

The amendment to the Life Act (expected sometime this year) will provide among other things legislative power to the Commissioner to formalise product disclosure rules which are currently in place as ISC guidelines. The rules will enable policybolders to make informed decisions based on price and product transparency and comparability, the product risks, and the potential for bias in product advice. The disclosure requirements will include information such as the benefits and costs of insurance to policyholders, cooling off period, dispute resolution facilities and applicable fees and charges.

\subsection{Industry self-regulation}

Codes of practices for the Life and General insurance industries commenced in 1995.

The broad objectives of the codes are consistent with those of the Insurance Contracts Act in that they seek to improve industry standards and practices. 
The life insurance code is intended to improve industry standards in the areas of product disclosure, sales practices, intermediary competencies and complaints handling. It is a statutory code of practice.

The general insurance Code of Practice is on the other hand self-regulatory and covers matters such as plain language documentation, claims handling procedures, training of agents as well as dispute resolution. Improvement in communication flow related to contract, price and redress mechanism is an important aim of the Code.

Brokers have also developed their own self-regulatory code and Insurance Broker Dispute Facility to deal with broker's professional conduct and related complaints.

These industry self-regulatory mechanisms have made an enormous contribution to achieving a more fair and transparent insurance market in Australia. Efforts made by the industry in the last few years have improved the flow of simple, plain language information to policyholders and have created a healthy business environment with reduced calls for a direct government intervention. The overall environment, for example, has led to a decline of complaints lodged with the general insurance dispute resolution scheme from 5171 in 94-95 to about 1985 in the 95-96 financial year.

\subsection{Inquiry into the Financial System}

One of the first decisions of the new Australian Government after winning of fice in 1996 was to announce a review of the financial system in the context of the significant market and technological changes that have occurred in the sector over the last decade. The Government established the Inquiry into the Financial System, chaired by Mr Stan Wallis, a distinguished Australian businessman, to review financial regulation in Australia, and to release its recommendations by 31 March 1997. Some of the major objectives of the Inquiry are to streamline the financial supervision, make Australian financial system internationally more competitive and provide for simpler but more effective consumer protection in the sector.

The Inquiry received a large number of submissions and undertook an intensive consultation process. There was a great deal of analysis and debate in respect of the future framework of financial supervision and regulation.

Naturally, there were different views within the financial sector and among bureaucracy on the way forward. One of the important issues involved was whether we still need the current prudential safeguards and government control or "caveat emptor" with full disclosure should be the way to go.

Notwithstanding its support for an increased used of disclosure as a regulatory tool, the ISC was of the strong view that there is still a need for financial supervision and government control. It was the ISC's opinion that a laissez faire approach to regulation in the financial sector which relies on information disclosure alone is inappropriate as it assumed:

- highly competitive markets with easy entry and exit and no sunk costs; and

- consumers with a high level of technical expertise, and up to date information. 
This approach is particularly inappropriate in the insurance sector with its complexities and sensitivities. It does not take into account costs arising from uncertainty, lack of confidence and monopolistic behaviour in the sector. It may reduce consumers welfare and it may result in a less competitive insurance sector. Consumers in insurance are less likely to "shop around" for the best value on the basis of complex disclosure documentation which requires a lot of financial and legal analysis and make little sense for ordinary consumers. In its Annual Report 1996 the Claims Review Panel said:

"Consumers appear to become aware of the limitations of their policy belatedly, after an event has occurred rather than when they purchase their policy"10.

Therefore, even if full disclosure of information in the insurance market is achieved, some issues still remain:

- Is the information read and understood by a reasonable person?

- Does the reasonable person assumption assume only a financially and legally literate population?

- Are the losses incurred by those "non-reasonable" people socially acceptable and preventable?

- Are the losses incurred by innocent third parties because of actions of those non reasonable socially acceptable and preventable?

and many others.

\section{Conclusion}

The uninterrupted flow of simple and plain language information is a most significant factor for the efficient functioning of the insurance market. Accordingly, governments have an important role to set and monitor the rules of fair play and communication in order to achieve the socially optimal outcome.

The issue of information disclosure deserves more public attention in insurance than in other financial sectors because of sector's specific nature, complex and multiple risks involved and the socially unacceptable consequences of market failure.

The questions that government constantly faces in dealing with information disclosure in insurance are:

- What information should be disclosed, by whom and for what purposes?

- Is the communication flow uninterrupted:

- is information received

- is information understood - reasonable person assumption and ethical and social issue of protecting those who in spite of full disclosure are still vulnerable

${ }^{10}$ Claims Review Panel Annual Report, 1996. 
In their regulatory activities in insurance the Australian Government and the ISC are also faced with the issue of balance between consumer protection objectives and excessive interference in commercial decisions of the market participants.

Intermediate tools available to Government such as information disclosure may be difficult to implement in insurance. Information disclosure in insurance requires significant amount of professional work and strong commitment from the industry and the government. It appears unlikely that the process will be self-initialised and self governed without government's initial push and continuous monitoring and control.

In Australia, a lot of attention in the last decade has been devoted to information disclosure related to product, price, redress mechanisms and disclosure related to factors relevant to the risk. Specific legislation dealing with communication flow introduced in the eighties, together with effective industry dispute resolution mechanism in the nineties, were of indispensable value for policyholders. The information about the product, price, redress mechanism, duty of disclosure has become clearer and more accessible. Selfregulatory, free of charge, dispute resolution mechanism has become an efficient and more frequently used alternative to litigation.

Disclosure of financial information is a more recent phenomenon in Australia. It followed international moves towards a more transparent and accountable financial market with an increased role of independent market evaluators. It is still to be decided how compatible are rating and government supervision and what should be their respective roles in the economy. However, it is a prevailing view among Australian financial regulators that we do need financial supervision in order to provide consumer protection and stability in the sector.

The Wallis Inquiry into the Financial System is due to release its recommendations on 31 March 1997. One of the more significant issues involved is information disclosure in future Australian financial regulation. Information disclosure is one of the most flexible and least intrusive regulatory tools which addresses the most important form of market failure in insurance: information asymmetry.

Nevertheless, some issues remain:

- Can information disclosure alone provide a reasonable and socially acceptable protection to policyholders and broader public in insurance?

- What to do with the "non-reasonable" part of the population which cannot comprehend complex legal and financial information?

- What should be the role of disclosure of financial information and rating agencies compared to government supervision of insurance? and, of course

- Does insurance continue to be so specific to deserve a special regulatory treatment in respect of information disclosure compared to other financial services? 


\section{REFERENCES}

Australian Law Reform Commission, Report No. 20, Insurance Contracts, AGPS, Canberra 1982.

AYRES, Ian, BRAITHWAITE John, Responsive Regulation, Oxford University Press, New York, 1992.

CORRIGAN, Challenges facing the International Community of Supervisors, Quarterly Review, Federal Reserve Bank of New York, volume 17 number 3, New York 1992.

Council of Financial Supervisors Annual Report 1994, Recent Developments in Regulation/ Supervision, Canberra 1994.

FRASER B., Reserve Bank of Australia, Financial Regulation and the Financial System Inquiry, Speech at "Trends" Luncheon, Canberra 1996.

GRUBER D., Assistant Commissioner-ISC, Proposed Reforms to the Insurance Contracts Act, Australian Insurance Law Association, Speeches at the Seminars in Melbourne, Sydney and Brisbane, November 1996.

GRUBER D., Assistant Commissioner-ISC, Rating or Regulation of Insurance Companies, Australian and New Zealand Insurance Law Associations, Speech at the JointAnnual Conference, Auckland 1996.

Insurance Enquiries \& Complaints Limited, Claims Review Panel Annual Report, Melbourne 1996.

International Association for Insurance, Insurance Contract Law, ed. M.Fontaine Vol I (1990) and Vol II (1992).

ISC, Guides (to the Insurance Act 1973, Insurance Contracts Act 1984, Insurance (Agents and Brokers) Act 1984), AGPS, Canberra 1996.

ISCAnnual Report 1993-94, Mission and Role of the Commission, Canberra, September 1994.

ISC, Submission to the Inquiry into the Financial System, Canberra, 1996.

LARKIN J., ROBERTS Dr D., ISC, Role of the ISC as a Financial Supervisor, Paper Presented to the Second Annual Colloquium of Superannuation Researchers, Melbourne University, 1994.

LLEWELLYN David T., Professor of Money \& Banking, Loughborough University, England, The Rationale and Institutional Structure of Financial Regulation, Commissioned Project for the ISC, Canberra, 1996.

MAGAT, WESLEY A. and VISCUSI Kip W., Informational Approaches to Regulation, Cambridge: MITPress, 1992.

MCCOMBIE R., Director-ISC, Insurance Contracts Act and the ISC, Speech at the Phillips Fox Seminars, Sydney, 1996.

OECD, Policy Issues in Insurance, Paris 1993.

OECD, Insurance and Other Financial Services Trends, Paris 1992.

POOLEY Ceorge, Commissioner-ISC, Prudential Supervision: Who Needs It? - An ISCPerspective, Speech at the ASFA Conference. Sydney, 1996.

ROTHSCHILD M., STIGLITZ J., Equilibrium in Competitive Insurance Markets: An Essay on the Economics of Imperfect Information, The Quarterly Journal of Economics, No 4, pages 629-650, November 1976.

SMITH R., Deputy Commissioner-ISC, Country Report-Australia, Speech at the 16th Meeting of the Asian Association of Insurance Commissioners, Singapore 1996. 
SMITH R., Deputy Commissioner-ISC, The Year That Was The YearAhead, Speech to the Australian Insurance Institute, Sydney, 1996.

STIGLITZ, Joseph E., Economics of the Public Sector, Norton \& Co., New York 198R.

The Economist, The Use and Abuse of Reputation - Ratings, April 6th 1996.

Treasury, Submission to the Inquiry into the Financial System, Canberra 1996.

Weimer/Vining, Policy Analysis, Concepts and Pract\&e, Prentice Hall Inc, New Jersey, USA, 1992. 